\title{
Inhibition of the Bicarbonate Exit Step in Urinary Acidification by a Disulfonic Stilbene
}

\author{
Loren H. Cohen, Allan Mueller, and Philip R. Steinmetz, Department of \\ Medicine, University of Iowa College of Medicine, Iowa City, Iowa 52242
}

A B S T R A C T Acidification of the luminal solution by the isolated turtle bladder involves $\mathrm{H}^{+}$secretion by a pump at the luminal membrane. The $\mathrm{OH}^{-}$dissociated in this process reacts with $\mathrm{CO}_{2}$ and forms $\mathrm{HCO}_{3}^{-}$which moves passively out of the cell across the serosal cell membrane. In the present study, this exit step for $\mathrm{HCO}_{3}^{-}$was inhibited by serosal addition of the disulfonic stilbene, SITS, an agent which is thought to bind to a transport protein at the serosal cell membrane. $90 \mathrm{~min}$ after serosal addition of $0.5 \mathrm{mM}$ SITS, $\mathrm{H}^{+}$ secretion decreased by $>80 \%$. In contrast, luminal addition of SITS had no effect. During inhibition of $\mathrm{H}^{+}$secretion by serosal SITS, overall cell $\mathrm{pH}$, measured by the 5,5-dimethyl-2,3-oxazolidinedione method, increased from $7.48 \pm 0.03$ to $7.61 \pm 0.02$. This increase of $0.13 \pm 0.02 \mathrm{pH} \mathrm{U}$ was associated with a much larger regional $\mathrm{pH}$ increase as judged from the decrement in the attainable $\mathrm{pH}$ gradient across the epithelium. After serosal SITS, this gradient was reduced from $2.88 \pm 0.06$ to $2.09 \pm 0.11 \mathrm{pH} \mathrm{U}$. In the absence of evidence for increased $\mathrm{H}^{+}$permeability or a change in the force of the $\mathrm{H}^{+}$pump, the gradient decrement of $0.79 \pm 0.08 \mathrm{U}$ reflects a similar $\mathrm{pH}$ increment on the cytoplasmic side of the pump.

SITS inhibits the exit of bicarbonate across the serosal cell membrane and, thereby, creates a compartment of high alkalinity in series with the pump. The increased electrochemical gradient across the active transport pathway is the primary factor in the inhibition of urinary acidification.

\section{INTRODUCTION}

Several lines of evidence suggest that the isolated turtle bladder acidifies the solution bathing its luminal surface by a process of active $\mathrm{H}^{+}$secretion located at

This work was presented in part before the National Meetings of the American Federation for Clinical Research in 1976 in Atlantic City, N. J. (1) and in 1977 in Washington, D. C. (2).

Received for publication 2 June 1977 and in revised form 12 December 1977. the luminal membrane (3-6). The solution bathing the serosal surface of the epithelium is alkalinized at almost the same rate $(3,6)$. From what is known about the electrochemical profile across the epithelium $(4,5)$, the movement of alkali from the cell interior to the serosal solution occurs passively down an electrochemical gradient. The hydroxyl ions generated behind the pump are buffered by $\mathrm{CO}_{2}$ and rapidly form $\mathrm{HCO}_{3}^{-}$in a carbonic anhydrase catalyzed reaction. The $\mathrm{HCO}_{3}^{-}$formed this way is thought to move across the basolateral membrane with little resistance, the luminal cell membrane being the major acid-base barrier.

The present investigation deals with the effects of a disulfonic stilbene, SITS, ${ }^{1}$ on the two cell membranes across which the transport processes of urinary acidification take place. It is shown that SITS, an agent which inhibits anion transport in a variety of tissues, inhibits acidification when added to the serosal but not to the luminal side of the epithelium. The mechanism by which serosal addition of SITS inhibits acidification is explored. These studies indicate that SITS inhibits the exit step for $\mathrm{HCO}_{3}^{-}$transport ${ }^{2}$ into the serosal solution and that this inhibition leads to increased alkalinity in a cellular compartment in series with the active transport pathway.

\section{METHODS}

Urinary bladders from the freshwater turtle, Pseudemys scripta, were mounted in lucite chambers as previously described (3). All experiments were performed in the shortcircuited state by voltage clamping except for brief periods when the open-circuit potential difference was recorded. Bladders were bathed on both sides with a $\mathrm{NaCl}$ Ringer's solution of the following composition in millimoles per liter:

\footnotetext{
${ }^{1}$ Abbreviations used in this paper: DMO, 5,5-dimethyl2,3-oxazolidinedione; $\mathrm{J}_{\mathrm{H}}$, rate of $\mathrm{H}^{+}$secretion; SITS, a disulfonic stilbene.

${ }^{2}$ For the purposes of this study, we refer to the anion moving out of the cell as $\mathrm{HCO}_{3}^{-}$. It is possible that some $\mathrm{OH}^{-}$dissociated in the process of acidification is transported as such from cell to serosal solution.
} 
$\mathrm{NaCl}, 114.4 ; \mathrm{KCl}, 3.5 ; \mathrm{MgCl}_{2}, 0.5 ; \mathrm{Na}_{2} \mathrm{HPO}_{4}, 2.0 ; \mathrm{CaCl}_{2}, 1.8$. In most experiments, the solutions were bubbled with air which had passed through $3-\mathrm{M} \mathrm{KOH}$ traps to remove all ambient $\mathrm{CO}_{2}$, and the rate of $\mathrm{H}^{+}$secretion $\left(\mathrm{J}_{\mathrm{H}}\right)$ was measured by $\mathrm{pH}$ stat titration (3) with both media maintained at $\mathrm{pH}$ 7.0. In some experiments in which sodium transport was abolished by $0.5 \mathrm{mM}$ ouabain, the serosal gas phase was $5 \% \mathrm{Co}_{2}$ in air, and $J_{H}$ was measured as the short-circuit current. In these experiments, the serosal $\mathrm{pH}$ was maintained at 5.8 to keep the $\mathrm{HCO}_{3}^{-}$concentration low. Previous studies have shown that the short-circuit current measures $J_{H}$ in bladders in which sodium transport is abolished by ouabain both in the absence (6) and presence (7) of exogenous $\mathrm{CO}_{2}$

After a stable $\mathrm{J}_{\mathrm{H}}$ was established by either of the two methods, 4-acetamido-4'-isothiocyano-2,2'-disulfonic stilbene, SITS (Polysciences, Inc., Warrington, Pa.), was added to the serosal or luminal solution in the dosage indicated. The SITS was freshly dissolved in the Ringer's solutions after the control periods.

In another series of bladders, the effect of SITS was examined from the distribution of the weak acid $\left[{ }^{14} \mathrm{C}\right] 5,5-$ dimethyl-2,3-oxazolidinedione $\left(\left[{ }^{14} \mathrm{C}\right] \mathrm{DMO}\right)$. Isotopic compounds $\left[{ }^{14} \mathrm{C}\right] \mathrm{DMO}$ and $\left[{ }^{14} \mathrm{C}\right]$ inulin were obtained from New England Nuclear, Boston, Mass., and were counted in a Beckman liquid scintillation counter, model LS-250 (Beckman Instruments, Inc., Fullerton, Calif.). Hemibladders from the same turtle were bathed in $\mathrm{NaCl}$ Ringer's to which $\left[{ }^{14} \mathrm{C}\right] \mathrm{DMO}$ was added. Serosal $\mathrm{pH}$ was held at $7.40 \pm 0.01$ by hand titration with $0.01 \mathrm{~N} \mathrm{HCl}$ or $0.01 \mathrm{~N} \mathrm{NaOH}$. Luminal $\mathrm{pH}$ was kept at 7.40 by $\mathrm{pH}$ stat titration. After a control $\mathrm{J}_{\mathrm{H}}$ was established for a minimum of $2 \mathrm{~h}$, SITS was added to the serosal solution of one hemibladder, the other serving as a control. The bladders were removed from the chambers and blotted dry with filter paper $30 \mathrm{~min}$ after the addition of SITS. They were weighed before and after drying at $100^{\circ} \mathrm{C}$ in a Precision Thelco oven (Scientific Company, Chicago, Ill.), for at least $3 \mathrm{~h}$ to determine tissue water. With this oven, dry weight was achieved by $90 \mathrm{~min}$. Tissue counts were extracted in 0.01 $\mathrm{N} \mathrm{HNO}_{3}$ for $15 \mathrm{~h}$. To insure that the extraction was complete, a series of bladders was solubilized with $1 \mathrm{M} \mathrm{KOH}$, and the residual tissue counts were measured. A quench correction was made by adding a known number of counts to the dissolved tissue. This maneuver verified that the extraction from the tissue was complete.

For measurement of the extracellular space, $\left[{ }^{14} \mathrm{C}\right]$ inulin was used in a separate series of bladders handled in an identical manner. The inulin space in control halves was not different from SITS-treated bladder halves, $41.7 \pm 4.7$ and $43.0 \pm 2.8 \%$, respectively.

The intracellular $\mathrm{pH}$ was calculated according to Waddell and Butler (8) with a DMO pK extrapolated to 6.27 at $23^{\circ} \mathrm{C}$ and an inulin space of $42.4 \%$. A validation of the DMO technique for the estimation of overall intracellular $\mathrm{pH}$ in the turtle bladder has been given (4). Evidence was presented that DMO is not actively transported nor significantly bound to cell constituents in the tissue. As has been considered previously, in a multicompartment system with a heterogenous $\mathrm{pH}$ (4) the distribution of a weak acid is determined by the mean $\mathrm{OH}^{-}$concentration. All values are given as mean \pm SEM for a surface area of $8 \mathrm{~cm}^{2}$ of exposed bladder.

\section{RESULTS}

Effect of serosal and luminal addition of SITS on $\mathrm{H}^{+}$secretion $\left(\mathrm{J}_{\mathrm{H}}\right)$ in the absence of exogenous $\mathrm{CO}_{2}$ and $\mathrm{HCO}_{3}^{-}$. Table I shows how the serosal addition of 0.5 $\mathrm{mM}$ SITS causes a progressive inhibition of $\mathrm{J}_{\mathrm{H}}$ as meas-
TABLE I

Inhibition of $\mathrm{H}^{+}$Secretion by Serosal Addition of SITS

\begin{tabular}{ccccc}
\hline & \multicolumn{4}{c}{$\mathrm{J}_{\mathrm{H}, \mu \mathrm{mol} / \mathrm{h}}$} \\
\cline { 2 - 5 } & & \multicolumn{3}{c}{ SITS, 0.5 mM } \\
\cline { 2 - 5 } & Control & $30 \mathrm{~min}$ & $60 \mathrm{~min}$ & $90 \mathrm{~min}$ \\
\hline 1 & 1.31 & 0.81 & 0.41 & 0.26 \\
2 & 1.11 & 0.55 & 0.00 & 0.00 \\
3 & 1.75 & 1.34 & 0.98 & 0.64 \\
4 & 1.34 & 0.88 & 0.44 & 0.26 \\
5 & 0.74 & 0.48 & 0.20 & 0.05 \\
6 & 1.05 & 0.53 & 0.20 & 0.00 \\
Mean & 1.22 & 0.76 & 0.37 & 0.20 \\
\pm SE & 0.14 & 0.13 & 0.14 & 0.10
\end{tabular}

$\mathrm{H}^{+}$secretion, $\mathrm{J}_{\mathrm{H}}$, was measured by $\mathrm{pH}$ stat titration in the absence of exogenous $\mathrm{CO}_{2}$. Values after addition of SITS are given at 30,60 , and $90 \mathrm{~min}$.

ured by $\mathrm{pH}$ stat titration. $\mathrm{J}_{\mathrm{H}}$ was inhibited by $38 \%$ at 30 min and by $84 \%$ at 90 -min in six experiments carried out in the absence of exogenous $\mathrm{CO}_{2}$.

In contrast to the inhibition produced by serosal SITS, luminal addition had no effect on the rate of $\mathrm{pH}$ stat titration. In five bladders, the control $\mathrm{J}_{\mathrm{H}}$ was $0.76 \pm 0.06 \mu \mathrm{mol} / \mathrm{h}$. $90 \mathrm{~min}$ after luminal addition of $0.5 \mathrm{mM}$ SITS, the $\mathrm{J}_{\mathrm{H}}$ was $0.82 \pm 0.10 \mu \mathrm{mol} / \mathrm{h}$.

Effect of serosal SITS on the short-circuit current in ouabain-treated bladders in the presence of $\mathrm{CO}_{2}$. Since $\mathrm{J}_{\mathrm{H}}$ was limited by the availability of $\mathrm{CO}_{2}$ in the $\mathrm{pH}$ stat studies, the effects of serosal SITS were also examined at high rates of secretion in the presence of exogenous $\mathrm{CO}_{2}$. Schwartz (7) has shown that $\mathrm{J}_{\mathrm{H}}$ reaches near maximal levels when $5 \% \mathrm{CO}_{2}$ is added to the serosal gas phase. In six bladders in which sodium transport was inhibited by $0.5 \mathrm{mM}$ ouabain $\mathrm{J}_{\mathrm{H}}$ was measured as the short-circuit current with $5 \%$ $\mathrm{CO}_{2}$ in the serosal gas phase. Serosal $\mathrm{HCO}_{3}^{-}$concentrations were maintained low by keeping the serosal $\mathrm{pH}$ at 5.8. Serosal addition of $0.5 \mathrm{mM}$ SITS reduced $\mathrm{J}_{\mathrm{H}}$ from $1.82 \pm 0.30$ to $0.35 \pm 0.07 \mu \mathrm{mol} / \mathrm{h}$ after $90 \mathrm{~min}$. This $81 \%$ inhibition of $\mathrm{J}_{\mathrm{H}}$ in the presence of $\mathrm{CO}_{2}$ was close to the $84 \%$ inhibition observed in the $\mathrm{CO}_{2}$-free system (Table I).

Transient reversal of SITS inhibition by exogenous $\mathrm{CO}_{2}$. Since SITS inhibits $\mathrm{J}_{\mathrm{H}}$ only from the serosal side and SITS is thought to inhibit anion transport by binding to a transport protein at the cell membrane, it is postulated that SITS interferes with the anion exit step of urinary acidification which consists of the movement of $\mathrm{HCO}_{3}^{-}$from cell to serosal solution. The accumulation of $\mathrm{HCO}_{3}^{-}$within the cell would inhibit the $\mathrm{H}^{+}$ pump. To explore this possibility, $\mathrm{J}_{\mathrm{H}}$ was inhibited by serosal SITS in four ouabain-treated bladders in the absence of exogenous $\mathrm{CO}_{2}$. When $\mathrm{J}_{\mathrm{H}}$ was inhibited by 
about $80 \%$, the serosal gas phase was changed to $5 \%$ $\mathrm{CO}_{2}$ in air, and serosal $\mathrm{pH}$ was maintained at 5.8 to avoid the introduction of $\mathrm{HCO}_{3}^{-}$. One of the experiments is shown in Fig. 1. The addition of $\mathrm{CO}_{2}$ caused a partial but transient restoration of $\mathrm{J}_{\mathrm{H}}$. The initial stimulation of $J_{H}$ suggests that the pump was capable of increasing its transport rate when the cellular alkalinity was reduced by $\mathrm{CO}_{2}$. The failure of $\mathrm{CO}_{2}$ to sustain $\mathrm{J}_{\mathrm{H}}$ can be attributed to the accumulation of newly generated $\mathrm{HCO}_{3}^{-}$which cannot pass through the exit sites blocked by SITS. If this interpretation is correct, cell $\mathrm{pH}$ should increase after SITS. Therefore, we estimated the apparent cell $\mathrm{pH}$ by means of the DMO technique.

Effect of inhibition of $J_{H}$ on overall cell $p H$. In Table II, values for the apparent cell $\mathrm{pH}$ are given for seven experiments in which bladder halves exposed to SITS were compared with control halves of the same bladder. The apparent cell $\mathrm{pH}$ in the control halves was 7.48 , a value comparable to that obtained in a previous study (4). In the bladder halves exposed to SITS, $\mathrm{J}_{\mathrm{H}}$ was inhibited by about $60 \%$ after $30 \mathrm{~min}$ and in each case, the cell $\mathrm{pH}$ was increased over that of the control half. Although the average increment of 0.13 $\pm 0.02 \mathrm{pH} \mathrm{U}$ was small, it was highly significant.

The DMO method provides an estimate of the average cellular $\mathrm{OH}^{-}$concentration. The apparent $\mathrm{pH}$ value of $7.61 \pm 0.02$ obtained during inhibition of $\mathrm{J}_{\mathrm{H}}$ by SITS could reflect a larger increase in regional $\mathrm{OH}^{-}$concentration.

Effect of serosal SITS on the maximal $p H$ gradient. If SITS causes an accumulation of $\mathrm{OH}^{-}$behind the pump, it would be expected to reduce the maximal concentration gradient for $\mathrm{H}^{+}$that can be generated across the epithelium. In Table III, the maximal $\mathrm{pH}$ gradient, $(\Delta \mathrm{pH})_{\mathbf{J}_{\mathbf{H}}=0}$, was measured before and after serosal addition of $0.2 \mathrm{mM}$ SITS in six ouabain-treated blad-

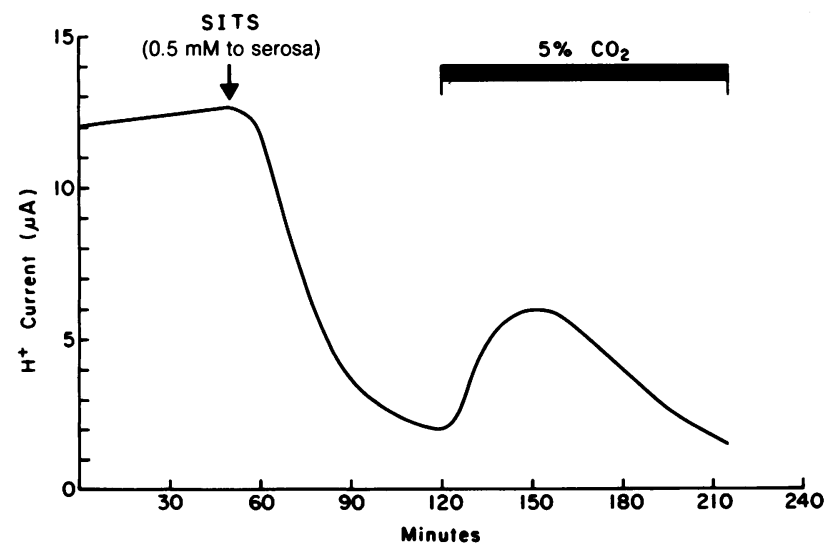

FIGURE 1 Transient stimulation of $\mathrm{J}_{H}$ by addition of exogenous $\mathrm{CO}_{2}$ in a SITS-inhibited bladder. After accumulation of $\mathrm{OH}^{-}$and $\mathrm{HCO}_{3}^{-}$within the cell, $\mathrm{J}_{\mathrm{H}}$ was again inhibited.
TABLE II

Effect of Serosal Addition of SITS* on $J_{H}$ and Apparent Cell $\mathrm{pH}$

\begin{tabular}{ccccccc}
\hline & \multicolumn{2}{c}{ Control halves } & & \multicolumn{3}{c}{ SITS halves } \\
\cline { 2 - 3 } \cline { 5 - 7 } & $\mathrm{J}_{\mathbf{H}}$ & Cell pH' & & $\mathrm{J}_{\mathbf{H}}$ & Cell $\mathrm{pH}^{\prime}$ & $\Delta \mathrm{pH}$ \\
\hline & $\mu$ mollh & & & $\mu$ mollh & & \\
1 & 1.81 & 7.48 & & 0.55 & 7.60 & 0.12 \\
2 & 1.04 & 7.59 & & 0.00 & 7.72 & 0.13 \\
3 & 0.70 & 7.35 & & 0.32 & 7.60 & 0.25 \\
4 & 1.42 & 7.54 & & 0.77 & 7.60 & 0.06 \\
5 & 1.36 & 7.50 & & 0.54 & 7.62 & 0.12 \\
6 & 0.66 & 7.46 & & 0.40 & 7.60 & 0.14 \\
7 & 1.20 & 7.44 & & 0.66 & 7.51 & 0.07 \\
Mean & 1.36 & 7.48 & & 0.54 & 7.61 & $0.13 \ddagger$ \\
\pm SE & 0.14 & 0.03 & & 0.07 & 0.02 & 0.02 \\
\hline
\end{tabular}

Control halves are compared to their respective SITStreated halves. $\mathrm{J}_{\mathrm{H}}$ was measured by the $\mathrm{pH}$ stat method in the absence of exogenous $\mathrm{CO}_{2}$. Apparent cell $\mathrm{pH}\left(\mathrm{pH}^{\prime}\right)$ was determined $30 \mathrm{~min}$ after addition of SITS.

* $0.2 \mathrm{mM}$.

$\ddagger P<0.005$.

ders in the absence of exogenous $\mathrm{CO}_{2}$. $\mathrm{J}_{\mathrm{H}}$ was measured as the short-circuit current, and $(\Delta \mathrm{pH})_{\mathrm{H}=0}$ was taken as the difference between the luminal $\mathrm{pH}$ at which the current became zero and the serosal $\mathrm{pH}$ of 7.40. Control $\mathrm{J}_{\mathrm{H}}$ was $0.64 \pm 0.08 \mu \mathrm{mol} / \mathrm{h}$, and $(\Delta \mathrm{pH})_{\mathrm{J}_{\mathrm{H}=0}}$ was $2.88 \pm 0.06 \mathrm{pH}$ U. About $30 \mathrm{~min}$ after SITS addition, $\mathrm{J}_{\mathrm{H}}$ was inhibited by $50 \%$ and $(\Delta \mathrm{pH})_{\mathrm{J}_{\mathrm{H}}=0}$ was reduced to $2.09 \pm 0.11 \mathrm{pH} \mathrm{U}$. The decrement in the achievable transepithelial $\mathrm{pH}$ gradient of $0.79 \pm 0.08$ was large. If the force of the pump is unaffected by SITS, then this decrement reflects a comparable $\mathrm{pH}$ increase in a critical region on the cytoplasmic side of the active transport pathway.

To exclude the possibility that the decrease in $(\Delta \mathrm{pH})_{\mathrm{J}_{\mathrm{H}=0}}$ was caused by an increase in the passive

TABLE III

Effect of SITS on the Maximal Transepithelial $p H$ Gradient, $(\Delta p H)_{J_{H}=0}$

\begin{tabular}{|c|c|c|c|c|}
\hline & $\mathbf{J}_{\mathbf{H}}$ & $\begin{array}{c}\text { Serosal } \\
\text { pH }\end{array}$ & $(\text { Luminal } \mathrm{pH})_{S_{\mathrm{H}}=0}$ & $(\Delta \mathrm{pH})_{J_{\mathrm{H}}=\mathbf{0}}$ \\
\hline \multirow{3}{*}{$\begin{array}{l}\text { Control } \\
\text { SITS }(0.2 \\
\mathrm{mM})\end{array}$} & $\mu \mathrm{mol} / \mathrm{h}$ & & & \\
\hline & $0.64 \pm 0.08$ & 7.40 & $4.52 \pm 0.06$ & $2.88 \pm 0.06$ \\
\hline & $0.32 \pm 0.03$ & 7.40 & $\begin{array}{c}5.31 \pm 0.11 \\
\text { (Control- } \\
\text { SITS) }\end{array}$ & $\begin{array}{l}2.09 \pm 0.11 \\
0.79 \pm 0.08\end{array}$ \\
\hline
\end{tabular}

Mean values $\pm \mathrm{SE}$ are given for six ouabain-treated bladders. The gas phase was $\mathrm{CO}_{2}$-free air. $(\Delta \mathrm{pH})_{J_{\mathrm{H}}=0}$ was determined 30 min after serosal addition of SITS. 
$\mathrm{H}^{+}$permeability of the bladder, the luminal $\mathrm{pH}$ was lowered $0.30 \mathrm{pH}$ U below the $\mathrm{pH}$ at which net $\mathrm{H}^{+}$ secretion was zero. The rate of loss of $\mathrm{H}^{+}\left(-\mathrm{J}_{\mathrm{H}}\right)$ from the luminal compartment was not altered by SITS $(n=4)$, hence, there was no evidence that the reduced gradient was caused by back diffusion of $\mathrm{H}^{+}$across the luminal membrane.

Alteratively, $(\Delta \mathrm{pH})_{\mathrm{J}_{\mathrm{H}=0}}$ might have been reduced by movement of $\mathrm{HCO}_{3}^{-}$from the cell into the luminal solution instead of the serosal solution. Since $(\Delta \mathrm{pH})_{\mathrm{H}=0}$ was determined as the condition of zero net current in ouabain-treated bladders, only a charge carrying $\mathrm{HCO}_{3}^{-}$flow would affect this value. The available evidence $(4,6,9,10)$, however, suggests that the luminal membrane is virtually impermeable to the diffusional flows not only of $\mathrm{H}^{+}$but also of $\mathrm{HCO}_{3}^{-}$. Any electroneutral $\mathrm{HCO}_{3}^{-}$secretion (see below paragraph) would not have been recorded by the current technique for the measurement of $(\Delta \mathrm{pH}) \mathrm{J}_{\mathrm{H}=0}$.

Effects of SITS on the transport of other ions. In all of the studies presented, the serosal $\mathrm{HCO}_{3}^{-}$concentration was kept low either by the use of a solution free of exogenous $\mathrm{CO}_{2}$ and $\mathrm{HCO}_{3}^{-}$at $\mathrm{pH} 7.0$ or 7.4 , or by lowering the serosal $\mathrm{pH}$ to 5.8 when the serosal gas phase was $5 \% \mathrm{CO}_{2}$. This design allowed us to focus on the disposition of alkali generated in series with the $\mathrm{H}^{+}$pump. Leslie et al. (11) and Oliver et al. (12) have described a separate transport system which is involved in the absorption of $\mathrm{Cl}^{-}$in exchange for secreted $\mathrm{HCO}_{3}^{-}$. This anion-exchange system is electroneutral and requires the presence of $\mathrm{HCO}_{3}^{-}$in the serosal solution. The effect of SITS on the transcellular $\mathrm{HCO}_{3}^{-}$movement from the serosal to the luminal side of the bladder has been explored in another study in which it was shown that $\mathrm{HCO}_{3}^{-}$secretion and $\mathrm{Cl}^{-}$absorption are not affected by serosal SITS (13), a result suggesting that there are separate sites for the exit of $\mathrm{HCO}_{3}^{-}$and the oppositely directed electroneutral $\mathrm{HCO}_{3}^{-}$flow.

Sodium fluxes were not measured in this study. An estimate of the net sodium absorption, however, was obtained from the sum of the short-circuit current and $\mathrm{H}^{+}$secretion measured simultaneously by $\mathrm{pH}$ stat titration (6). In five pairs of hemibladders, the net sodium absorption was $347 \pm 28,352 \pm 24$, and $347 \pm 24 \mu \mathrm{A}$ in the control halves at 0,60 , and $90 \mathrm{~min}$, respectively, and $355 \pm 29,284 \pm 18$ and $250 \pm 16 \mu \mathrm{A}$ in the halves exposed to $0.5 \mathrm{mM}$ serosal SITS. In SITS-treated halves the inhibition of the net sodium absorption was significant $(P<0.01)$ and increased from $20 \%$ at $60 \mathrm{~min}$ to $30 \%$ at 90 min. Ehrenspeck and Brodsky (14) found no significant inhibition of the net sodium absorption under somewhat different conditions.

\section{DISCUSSION}

Studies by Rothstein, Cabantchik, and Knauf (15-17) in erythrocytes, indicate that the disulfonic stilbenes inhibit anion transport by binding to a membrane protein, and that they appear to react with a site near the outside of the cell membrane (15-18). Inhibition of anion transport by SITS has been demonstrated in a variety of other tissues as well (19-21). Ehrenspeck and Brodsky (14) reported that SITS added to the serosal side of the turtle bladder inhibits anion transport as judged from the short-circuit current in sodium-free media. Furthermore, a preliminary report by Ehrenspeck et al. (22) suggests that the stilbenes bind to a protein located in the serosal cell membrane.

Our studies confirm the observation that in the absence of sodium transport the short-circuit current in turtle bladder is inhibited by SITS and specifically explore the mechanisms by which SITS inhibits urinary acidification. The results show that urinary acidification is inhibited by serosal but not by luminal addition of SITS. Since the $\mathrm{H}^{+}$pump is located at the luminal membrane, it is likely that the inhibition is exerted at a transport site at the serosal membrane, presumably the SITS binding protein. Previous studies have shown that the rate of alkalinization of the serosal compartment is about the same as the rate of $\mathrm{H}^{+}$secretion into the luminal compartment when the small rate of lactate production, about $0.1 \mu \mathrm{mol} / \mathrm{h}$, is taken into account $(3,6,23)$. It is likely, therefore, that SITS inhibits the exit of $\mathrm{HCO}_{3}^{-}$from cell interior to the serosal compartment and that SITS does not inhibit the $\mathrm{H}^{+}$pump directly. Similarly, the observation that the $\mathrm{H}^{+}$pump can be stimulated transiently by exogenous $\mathrm{CO}_{2}$ suggests that the transport system at the luminal membrane is not the primary site of inhibition.

Most of the factors regulating the rate of $\mathrm{H}^{+}$secretion are thought to operate at the active transport system for $\mathrm{H}^{+}$. They are the electrochemical gradient across the active transport pathway, the supply of metabolic energy to the pump system and the availability of carbonic anhydrase and $\mathrm{CO}_{2}$ for the buffering of $\mathrm{OH}^{-}$generated behind the pump (6). Once the dissociated $\mathrm{OH}^{-}$ions have reacted with $\mathrm{CO}_{2}$, the $\mathrm{HCO}_{3}^{-}$ ions formed this way are thought to freely move down an electrochemical gradient from the cytoplasm across the basal cell membrane into the serosal solution (3-6). Under the usual conditions, this exit step for $\mathrm{HCO}_{3}^{-}$ has not been considered rate-limiting for urinary acidification.

The observed inhibition of $\mathrm{J}_{\mathrm{H}}$ after serosal addition of SITS, however, is most easily explained by a marked reduction in the conductance for $\mathrm{HCO}_{3}^{-}$across the basolateral cell membrane. As a consequence of the impaired exit of $\mathrm{HCO}_{3}^{-}$, the epithelial cells would become more alkaline. By means of the DMO technique, a small but significant increase in the overall cell $\mathrm{pH}$ was indeed demonstrated. The measured increase in the mean cellular $\mathrm{OH}^{-}$concentration, however, provides no information on the distribution of the increased $\mathrm{OH}^{-}$ 
concentration within the cells. The increase could be caused by a very high $\mathrm{OH}^{-}$concentration in a small region or by a small increase in the bulk of the epithelium. The possibility of a large concentration change in a small region was approached by studying the transepithelial $\mathrm{pH}$ gradient that stops net $\mathrm{H}^{+}$secretion, $(\Delta \mathrm{pH}) \mathbf{J}_{\mathrm{H}=\mathbf{0}}$.

If the proton motive force of the pump and the passive $\mathrm{H}^{+}$permeability are unaffected, then any change in $(\Delta \mathrm{pH})_{\mathrm{J}_{\mathrm{H}}=0}$ would be a function of a change in the electrochemical activity of $\mathrm{H}^{+}$on the cytoplasmic side of the active transport pathway. The value $(\Delta \mathrm{pH})_{\mathrm{J}_{\mathrm{H}}=0}$ would serve as a probe of this activity on the inside of the pump pathway. According to such an analysis, ${ }^{3}$ the cellular compartment adjacent to and in series with the pump increased its $\mathrm{pH}$ by $0.79 \mathrm{U}$ from 7.48 to 8.27 during SITS inhibition of acidification. Steinmetz and Lawson (24) and Beauwens and Al-Awqati (10) have shown that the luminal membrane has a very low passive $\mathrm{H}^{+}$permeability, and that $\mathrm{J}_{\mathrm{H}}$ is closely controlled by the electrochemical gradient across the luminal membrane (9). In these previous studies, however, the luminal $\mathrm{pH}$ was varied, and the cell $\mathrm{pH}$ remained near 7.4 or 7.5 , as judged from DMO studies (4) and the

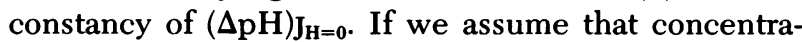
tion changes across the active transport pathway have similar effects on $J_{H}$, whether they are applied from the luminal or from the cytoplasmic side of the membrane, then the accumulation of $\mathrm{OH}^{-}$and $\mathrm{HCO}_{3}^{-}$on the cytoplasmic side of the pump in SITS-treated bladders could account for much of the observed inhibition of $\mathrm{J}_{\mathrm{H}}$.

For several reasons it is difficult to quantitate the inhibitory effect of a $\Delta \mathrm{pH}$ at the cytoplasmic side of the active transport pathway. First of all, $\Delta \mathrm{pH}$ effects on the two sides of the membrane are not necessarily symmetrical. The $\mathrm{pH}$ of the cytoplasmic side of the pump is probably regulated in a much narrower range than that of the luminal side. The increased alkalinity on the inside of the transport pathway would be expected to decrease the supply of protons to the pump site and also might inhibit certain metabolic reactions supplying energy for the translocation of protons.

It should be noted that the evidence for increased alkalinity was obtained at $50-60 \%$ inhibition of $\mathrm{J}_{\mathrm{H}}$. Prolonged inhibition of $\mathrm{J}_{\mathbf{H}}$ by SITS resulted in a decrease in the cellular alkalinity, as judged from $(\Delta \mathrm{pH})_{J_{H}=0}$, a result consistent with the interpretation that factors other than the local gradient come into play with time. Such secondary factors might also account for the modest reduction in the estimated sodium current observed after $1 \mathrm{~h}$ of exposure to serosal SITS when $\mathrm{J}_{\mathrm{H}+}$ was inhibited by $70 \%$.

\footnotetext{
${ }^{3}$ Previous studies (9) have shown that the imposition of an electrical gradient $(\Delta \psi)$ reduces $\mathrm{J}_{\mathrm{H}}$ in the same manner as a concentration gradient $(\Delta \mathrm{pH})$. For the purposes of this analysis the changes are expressed in $\mathrm{pH}$ units.
}

Relatively little is known about the role of the exit step for $\mathrm{HCO}_{3}^{-}$in the regulation of urinary acidification. In the turtle bladder, as shown in this study, the high permeability of the basolateral cell membrane for $\mathrm{HCO}_{3}^{-}$is dramatically reduced by exposure to the disulfonic stilbene, SITS. As a result, the exit step for $\mathrm{HCO}_{3}^{-}$becomes rate-determining for $\mathrm{H}^{+}$secretion. Studies by Frömter et al. (25) and Filho and Malnic (26) suggest that the peritubular cell membrane of the rat proximal tubule is also freely permeable to $\mathrm{HCO}_{3}^{-}$ and that carbonic anhydrase inhibitors reduce this permeability. Ullrich et al. (27) recently reported that SITS causes a marked inhibition of $\mathrm{H}^{+}$secretion by the proximal tubule only when applied to the peritubular side. It appears, therefore, that the exit step for $\mathrm{HCO}_{3}^{-}$is sensitive to SITS in different urinary epithelia which are capable of acidification. The results in turtle bladder indicate that the serosal addition of SITS creates a compartment ${ }^{4}$ of high alkalinity in series with the $\mathrm{H}^{+}$pump. The increased concentration gradient across the active transport pathway is the primary factor in the inhibition of urinary acidification.

\section{ACKNOWLEDGMENTS}

This research was supported by grants from the National Institutes of Health, AM 17568 and HL 14388. Part of this work was carried out while Dr. L. H. Cohen was the recipient of a National Kidney Foundation Fellowship under the Matching Fund Program of the Kidney Foundation of Iowa.

\section{REFERENCES}

1. Cohen, L. H., A. Mueller, and P. R. Steinmetz. 1976. Inhibition of the anion exit step in urinary acidification by a disulfonic stilbene. Clin. Res. 24: 396A. (Abstr.)

2. Cohen, L. H., and P. R. Steinmetz. 1977. Mechanism by which the serosal exit step for $\mathrm{HCO}_{3}^{-}$affects the transport rate of $\mathrm{H}^{+}$in urinary acidification. Clin. Res. 25: 428A. (Abstr.)

3. Steinmetz, P. R. 1967. Characteristics of hydrogen ion transport in urinary bladder of water turtle.J. Clin. Invest. 46: $1531-1540$.

4. Steinmetz, P. R. 1969. Acid-base relations in epithelium of turtle bladder: Site of active step in acidification and role of metabolic $\mathrm{CO}_{2}$. J. Clin. Invest. 48: 1258-1265.

5. Hirschhorn, N., and H. S. Frazier. 1971. Intracellular electrical potential of the epithelium of turtle bladder. Am. J. Physiol. 180: 641-649.

6. Steinmetz, P. R. 1974. Cellular mechanisms of urinary acidification. Physiol. Rev. 54: 890-956.

7. Schwartz, J. H. 1976. $\mathrm{H}^{+}$current response to $\mathrm{CO}_{2}$ and carbonic anhydrase inhibition in turtle bladder. Am. J. Physiol. 231: 565-572.

8. Waddell, W. J., and T. C. Butler. 1959. Calculation of intracellular $\mathrm{pH}$ from the distribution of 5,5-dimethyl2,4-oxazolidinedione (DMO). Application to skeletal muscle of the dog. J. Clin. Invest. 38: 720-729.

9. Al-Awqati, Q., A. Mueller, and P. R. Steinmetz. 1977.

${ }^{4}$ This physiologic analysis pertains to the epithelial cells involved in $\mathrm{H}^{+}$secretion but does not provide information on whether $\mathrm{H}^{+}$secretion is the function of all cells or of a population of carbonic anhydrase-rich cells (28). 
The transport of $\mathrm{H}^{+}$against electrochemical gradients in turtle urinary bladder. Am. J. Physiol. 233: F502-F508.

10. Beauwens, R., and Q. Al-Awqati. 1976. Active $\mathrm{H}^{+}$transport in the turtle urinary bladder: Coupling of transport to glucose oxidation. J. Gen. Physiol. 68: 421-439.

11. Leslie, B. R., J. H. Schwartz, and P. R. Steinmetz. 1973. Coupling between $\mathrm{Cl}^{-}$absorption and $\mathrm{HCO}_{3}^{-}$secretion in turtle urinary bladder. Am. J. Physiol. 225: 610-617.

12. Oliver, J. A., S. Himmelstein, and P. R. Steinmetz. 1975. Energy dependence of urinary bicarbonate secretion in turtle bladder. J. Clin. Invest. 55: 1003-1008.

13. Husted, R. F., L. H. Cohen, and P. R. Steinmetz. 1977. Selectivity of inhibition of anion flows by a disulfonic stilbene (SITS) in turtle urinary bladder. Physiologist. 20: 46.

14. Ehrenspeck, G., and W. A. Brodsky. 1976. Effects of 4acetamido-4'-isothiocyano-2,2'-disulfonic stilbene on ion transport in turtle bladders. Biochim. Biophys. Acta. 419: 555-558.

15. Rothstein, A., Z. I. Cabantchik, and P. Knauf. 1976. Mechanism of anion transport in red blood cells: role of membrane proteins. Fed. Proc. 35: 3-10.

16. Knauf, P. A., and A. Rothstein. 1971. Chemical modification of membranes. I. Effects of sulfhydryl and amino reactive reagents on anion and cation permeability of the human red blood cell. J. Gen. Physiol. 58: 190-210.

17. Cabantchik, Z. I., and A. Rothstein. 1974. Membrane proteins related to anion permeability of human red blood cells. II. Effects of proteolytic enzymes on disulfonic stilbene sites of surface proteins. J. Membr. Biol. 15: 227-248.

18. Maddy, A. H. 1964. A fluorescent label for the outer components of the plasma membrane. Biochim. Biophys. Acta. 88: 390-399.
19. Levinson, C. 1975. The interaction of chloride with the sulfate transport system of Ehrlich ascites tumor cells. J. Cell Physiol. 87: 235-244.

20. Thomas, R. C. 1976. Ionic mechanism of the $\mathrm{H}^{+}$pump in a snail neurone. Nature (Lond.). 262: 54-55.

21. Russell, J. M., and W. F. Boron. 1976. Role of chloride transport in regulation of intracellular pH. Nature (Lond.). 264: 73-74.

22. Ehrenspeck, G., W. A. Brodsky, R. Kinne, and Z. I. Cabantchick. 1976. Ion-selective, transport-related proteins in epithelial cell membranes. Clin. Res. 24: 467A. (Abstr.)

23. Schwartz, J. H., and P. R. Steinmetz. 1977. Metabolic energy and $\mathrm{PCO}_{2}$ as determinants of $\mathrm{H}^{+}$secretion by turtle urinary bladder. Am. J. Physiol. 233: F145-F149.

24. Steinmetz, P. R., and L. R. Lawson. 1971. Effect of luminal $\mathrm{pH}$ on ion permeability and flows of $\mathrm{Na}^{+}$and $\mathrm{H}^{+}$in turtle bladder. Am. J. Physiol. 220: 1573-1580.

25. Frömter, E., K. Sato, and K. Gessner. 1975. Electrical studies on the mechanism of $\mathrm{H}^{+} / \mathrm{HCO}^{3}$ transport across rat kidney proximal tubule. Proc. Int. Congr. Nephrol. 6: $108-112$.

26. Filho, E. M. G., and G. Malnic. 1976. pH in cortical peritubular capillaries of rat kidney. Pflugers Arch. Eur. J. Physiol. 363: 211-217.

27. Ullrich, K. J., G. Capasso, G. Rumrich, F. Papavassiliou, and S. Kloss. Coupling between proximal tubular transport processes. Studies with ouabain, SITS and $\mathrm{HCO}_{3}^{-}$ free solutions. Pflugers Arch. Eur. J. Physiol. 368: 245-252.

28. Schwartz, J. H., S. Rosen, and P. R. Steinmetz. 1972. Carbonic anhydrase function and the epithelial organization of $\mathrm{H}^{+}$secretion in turtle urinary bladder. J. Clin. Invest. 51: 2653-2662. 